provements in behaviour and arousal have been reported. ${ }^{18}$ Exton-Smith et al suggested that higher doses of such agents may produce improvements in cognition. ${ }^{19}$ Perhaps the emphasis of the debate should be changed to consideration of which patients are likely to benefit from enhancement of their cerebral metabolism. Is it those with least derangement of metabolism and little structural damage or those with most derangement of metabolism and most structural damage? If the proposed division of Alzheimer's disease is confirmed then clinical trials in carefully characterised homogeneous groups of patients may produce more meaningful results.

Many of the drugs in the miscellaneous group have been reviewed by Reisberg. ${ }^{20}$ Clinical trials have been few, and the physiopathological basis for their use is in most cases tenuous. Opioid overactivity is said to occur in Alzheimer's disease due to a reduction in the inhibitory influence of $\gamma$-aminobutyric acid on opiate systems: and so opiate antagonists (naloxone) have been proposed as a treatment of Alzheimer's disease. Clinical trials of naloxone have been inconclusive. Vasopressin has also been postulated to have an enhancing effect on memory in normal people, ${ }^{21}$ but no improvement in memory function has been shown in people with brain damage. ${ }^{22}$

A new class of cerebrally active substances, the "nootropics," has been used in dementia with inconclusive results. An example is piracetam, a cyclic derivative of $\gamma$-aminobutyric acid, which is said to increase synthesis of adenosine-5'-triphosphate and enhance release of acetylcholine in the hippocampus. Further investigations are being undertaken to study its use in combination with precursors of choline synthesis.

The cholinergic treatment strategy has been reviewed by Johns et al and Rosenburg et al. ${ }^{23}$ This strategy has the merit of being derived from established biochemical abnormalities in Alzheimer's disease. Three approaches have been tried in attempts to enhance cholinergic activity: use of precursors (choline or lecithin); use of anticholinesterases (physostigmine); or use of muscarinic receptor agonists (arecholine). Clinical trials of precursors have been almost uniformly negative,,$^{23}$ and giving such substances causes practical problems as they are bulky -and it is also debatable whether such agents increase the amount of central cholinergic activity. ${ }^{23}$ Anticholinesterases have produced clinical improvement in some patients, but the short half life of physostigmine limits its usefulness. Both these strategies are open to the criticism that they are attempting to induce change in the defective presynaptic part of the cholinergic system. The third strategy, use of muscarinic agonists, avoids this criticism as the muscarinic receptors are intact. Many such agents, however, have short half lives. Longer acting agents such as oxotremarine await evaluation.

It is still too early to evaluate the place of the cholinergic strategy in the treatment of Alzheimer's disease. Levy has argued that to expect clinical improvement may be asking too much of such drugs, and that drug trials should be designed to assess whether the test substance can slow down the disease process rather than producing measurable improvement. ${ }^{25}$

Does discovery of cholinergic abnormalities in Alzheimer's disease bring promise of a therapeutic breakthrough akin to those which have occurred in Parkinson's disease as the result of identifying a dopamine deficiency? Such a parallel assumes that the deficit in the cholinergic system is the fundamental lesion in Alzheimer's disease, and this assumption is not yet entirely upheld by current pathophysiological findings; nor have attempts to make good that deficiency had unequivocal success. The current generation of "antidementia drugs" is heterogeneous, containing both drugs of great theoretical interest and of rational derivation and others that seem inherently less likely to be relevant or useful. For the present even those few that have shown some consistent improvements seem to offer neither sufficiently practical nor sufficiently sustained benefits to justify their general use-outside a research setting.

JANE BYRNE Lecturer

TOM ARIE Professor

Department of Health Care of the Elderly,

Queen's Medical Centre,

Nottingham NG7 2UH

1 Bondareff W. Age and Alzheimer's disease. Lancet 1983;i:1447.

Mountioy CQ, Rossor MN, Iversen LL, Roth M. Correlation of cortical cholinergic and GABA deficits with quantitative neuropathological findings in senile dementia. Brain 1984;107:507-18.

Davies P, Katzman R, Terry RD. Reduced somatostatin-like immunoreactivity in cerebral cortex from cases of Alzheimer disease and Alzheimer senile dementia. Nature 1980;288:279-80.

4 Perry EK, Tomlinson BE, Blessed G, Perry RH, Cross AJ, Crow TJ. Neuropathological and biochemical observations on the noradrenergic system in Alzheimer's disease. I Neurol Sci
1981;51:279-87.

Mann DMA, Lincoln J, Yates PO. Changes in the monoamine containing neurones of the human CNS in senile dementia. Br $\mathcal{Y}$ Psychiatry 1980;136:533-54

6 Benton JS, Bowen DM, Allen SJ, et al. Alzheimer's disease as a disorder of the isodentritic core. Lancet 1982;i:456.

7 Perry EK, Marshall EF, Blessed G, et al. Decreased imipramine binding in the brains of patients with depression. Br $\mathcal{F}$ Psychiatry 1983;142:188-92.

8 Yates CM, Allison Y, Simpson J, Maloney AF, Gordon A. Dopamine in Alzheimer's disease and senile dementia. Lancet 1979;ii:851-2.

9 Ball MJ, Hachinski V, Fox A, et al. A new definition of Alzheimer's disease: a hippocampal dementia. Lancet 1985; i: 14-6.

10 Hyman BT, van Hoesen GW, Damasio AR, Barnes CL. Alzheimer's disease: cell-specific pathology isolates the hippocampal formation. Science 1984;225:1168-70.

11 Grady CL. Neuropsychology and cerebral metabolism in normal aging. In: Cutler NR, moderator. Brain imaging and dementia. Ann Intern Med 1984;101:358-60.

12 Cutler NR. Brain metabolism in Alzheimer's disease. In: Cutler NR, moderator. Brain imaging and dementia. Ann Intern Med 1984;101:360-2.

13 Chase TN, Foster NL, Fedio P, Brooks R, Mansi L, Di Chiro G. Regional cortical dysfunction in Alzheimer's disease as determined by positron emission tomography. Ann Neurol 1984; 15(suppl): $170-4$.

14 Fieschi C, Lenzi GH. The aging brain and its metabolic balance: positron emission tomography results and prospects. In: Samuel D, Algeri S, Gershon S, Grimm VE, Tuffano G, eds. Aging of the brain. Vol 22. New York: Raven Press, 1983:123-31.

15 Anonymous. Vasodilators in senile dementia [Editorial]. Br Med $\mathcal{J}$ 1979;ii:511-2.

16 Branconnier RJ. The efficacy of cerebral metabolic enhancers in the treatment of senile dementia. Psychopharmacol Bull 1983;19(2):212-9.

17 Yesavage JA, Tinklenberg JR, Hollister LE, Berger PA. Vasodilators in senile dementia: a review of the literature. Arch Gen Psychiatry 1979;36:220-3.

18 McDonald RJ. Hydergine: a review of 26 clinical studies. Pharmakopsychiatrie 1979;12:407-22.

19 Exton-Smith AN, Piper M, Phillips M, Simpson J. Clinical experiences with ergot alkaloids. In: Agnoli A, Crepaldi G, Spano PF, Trabucchi M, eds. Aging brain and ergot alkaloids. New York: Raven Press, 1983:323-8.

20 Reisberg B, London E, Ferris SH, Anand R, deLeon MJ. Novel pharmacological approaches in the treatment of senile dementia of the Alzheimer type. Psychopharmacol Bull 1983;19(2):220-5.

21 Weingartner $\mathrm{H}$, Gold $\mathrm{P}$, Ballenger JC, et al. Effects of vasopressin on human memory functions. Science 1981;211:601-3.

22 Fewtrell WD, House AO, Jamie PF, Oates MR, Cooper JE. Effects of vasopressin on memory and new learning in a brain injured population. Psychol Med 1982;12:423-5.

23 Johns CA, Greenwald BS, Mohs RC, Davis KL. The cholinergic treatment strategy in aging and dementia. Psychopharmacol Bull 1983;19(2):185-97.

24 Rosenburg GS, Greenwald B, Davis KL. Pharmacologic treatment of Alzheimer's disease: an overview. In: Reisberg B, ed. Alzheimer's disease the standard reference. New York: Free Press, 1983:329-39.

25 Levy R. Choline in Alzheimer's disease. Lancet 1978;ii:944-5.

\section{What do you work with?}

The days are gone when patients working in industry handled only a few harmful substances such as lead, brass, and silica. Rapid advances in technology have resulted in workers being exposed to a much wider range of harmful or possibly harmful substances. No doctor can have a full knowledge of all forms of industrial exposure, so what action should he take when he or she (or increasingly nowadays the patient) raises the question "could the illness be due to something at work?” 
Firstly, the patient's medical and occupational history must be carefully reviewed, asking specifically about materials handled at work. Ask about a patient's work rather than his "job," for most of us warm to this approach, and people are pleased to explain what they do, what it entails, and what they handle. 'After all, "labourers" do not just dig holes in the road or carry bricks up ladders. They may work in diverse places such as a chemical factory, a foundry, or a cotton mill, while a "stoker" may well spend all day in a white coat seated in front of a control panel. Surprisingly, the construction industry (often recorded as "building" in medical notes) includes demolition, such as cutting through painted steel, which is how building workers get lead poisoning.

Secondly, when the substance produces an acute effect direct questions should show the relation between symptoms and work; one useful line is evidence of remissions at weekends and holiday periods. The clinical effects of exposure to toxic material may not appear until a few hours after exposure. Patients may wake up breathless at night from something they have handled during the day. Occupational asthma is a good example of a disorder in which both "immediate" and "non-immediate" effects may occur. ${ }^{2}$ Sensitisation, usually of the skin or respiratory tract, may appear soon after starting work with a new substance, or it may appear only after several years of work with the substance concerned. Long term effects, such as occupational cancers, may take 20 years or more to develop and thus the link with previous industrial exposure may be harder to substantiate, especially if the employee has left the suspect job some years before.

Thirdly, a frequently forgotten but most useful question is whether fellow workers have similar symptoms or illnesses, remembering that colleagues at work share infections as well as exposure to environmental hazards.

Once the doctor suspects an occupational cause for disease identifying the precise cause may be difficult because the patient may know only the name of an apparently obscure chemical or, worse still, a meaningless trade name. This, however, is becoming less of a problem than it was because it is now well recognised that workers should not be exposed to substances which they or their employer know nothing about. Employees need to have information and instructions about the substances they handle for they cannot reasonably be expected to cooperate with preventive measures unless they are well informed. ${ }^{3}$ The Health and Safety at Work Act requires employers to provide adequate information and training in such matters, ${ }^{34}$ and patients often now arrive at the surgery carrying specially prepared leaflets.

If the employer does not know about the harmful effects (or the absence of harmful effects) of a substance the same Act obliges manufacturers, suppliers, and others to provide adequate information about any measures that are necessary to protect the health and safety of the user. ${ }^{45}$ Furthermore, when such information is not available the manufacturer or supplier may be obliged to undertake research to eliminate or minimise any risks to health and safety.

If the doctor feels disinclined to pursue the matter directly with the employer he may contact the occupational physician (if there is one) or a medical colleague in the Employment Medical Advisory Service, to be found under "Health and Safety Executive" in the telephone directory. Unfortunately, this may not yield the desired information because the Health and Safety at Work Act (section 28) restricts the freedom of employment medical advisers to pass information on to other doctors, though it seems they may pass it on to officers of local authorities, water authorities, or police constables. ${ }^{6}$ Nevertheless, despite these restrictions employment medical advisers are generally extremely helpful. Perhaps things will be easier if new regulations, now in draft form, become law. ${ }^{7}$

Professor of Occupational Health,
University of Manchester,

W R LEE

Manchester M13 9PT

1 Finkel AJ. Hamilton and Hardy's industrial toxicology. 4th ed. London: John Wright, 1983:1-2.

2 Morgan WKC, Seaton A. Occupational lung diseases. 2nd ed. Philadelphia: W B Saunders Company, 1984:502.

3 Drake CD, Wright FB. Law of health and safery at work. London: Sweet and Maxwell, 1983:78,92. Health and Safery at Work Act 1974. London: HMSO, 1974. (Section 2(2)(c).)

Health and Safety at Work Act 1974. London: HMSO, 1974. (Section 6 .

Health and Safery at Work Act 1974. London: HMSO, 1974. (Section 28.)

Health and Safety Commission. Control of substances hazardous to health. Consultative document. Draft regulations and draft approved code of practice. London: HMSO, 1984.

\section{Psychogenic cough in childhood}

All those concerned with the care of children and adolescents will be familiar with the young patient who seems relatively well apart from a persistent cough. The child is usually not particularly worried about the symptom-unlike his parents, teachers, and friends, who find it intensely irritating. The cough may be a sufficient social nuisance to prevent the child attending school for weeks or even months at a time. Sometimes the general practitioner will work systematically through the Mims list of cough suppressants, expectorants, and antibiotics with little, if any, improvement. Many of the children will eventually be referred to a paediatric or chest clinic, where he or she will often have to submit to numerous investigations-all the results of which eventually prove negative.

The condition these children have is variously called psychogenic cough, psychogenic cough tic, ${ }^{1}$ or honking. ${ }^{2}$ The diagnostic features which should alert the clinician include total absence of cough during sleep, often a harsh, explosive barking quality to the cough said to be reminiscent of the Canadian goose-hence the term "honker,"' and the ability of the affected child to produce the cough on request. Most honkers are between 6 and 14 years. Characteristically the symptoms start at a time when the child has an upper respiratory tract infection. Some appear to be under psychological stress, including school phobias and parental strife, ${ }^{3}$ and in a recent publication most were claimed to have either absent or depressed gag and corneal reflexes, features which are often associated with symptoms of conversion hysteria. ${ }^{4}$

Clearly organic causes must be excluded before the clinician makes a diagnosis of psychogenic cough. Asthma can present with recurrent cough with little or no wheezing or breathlessness, particularly in the younger child. ${ }^{5}$ Other causes include whooping cough, an aspirated foreign body, bronchiectasis, and cystic fibrosis. Whether or not a postnasal drip secondary to upper respiratory tract infection can itself produce persistent coughing is doubtful ${ }^{6}$-it may simply reflect the coexistence of pathological processes in the upper and lower respiratory tract. ${ }^{7}$ An older child should certainly be gently questioned about smoking. Clinically all that is normally needed is a careful history and examination, peak flow measticements before and after $\beta_{2}$ adrenergic stimulants, and chest radiographs (with views in inspiration 